\title{
A Review on Agricultural Problems and Their Management in Ethiopia
}

\author{
Bulti Merga ${ }^{1, a, *}$, Abdulatif Ahmed ${ }^{1, b}$ \\ ${ }^{\text {IS }}$ chool of Plant Sciences, Haramaya University, Ethiopia \\ *Corresponding author
}

A R T I C L E I N F O
Review Article
Received : 20/04/2019
Accepted : 01/08/2019

Keywords: Optimum scheduling Parasitic weeds Waterlogging Soil salinity and acidity Ethiopia

\author{
A B S T R A C T
}

Ethiopia's agricultural production has been challenged by waterlogging, salinity, acidity, parasitic weed, and irrigation scheduling problems which has resulted in lower yields than the potential. Waterlogging is the main drainage problem in the small scale irrigation schemes in the Vertisols dominated highland areas while salinity and salinization is a common phenomenon in the large and medium scale irrigation schemes located in the lowlands of the country's major river basins with predominantly salt affected soils. Soil acidity and associated low nutrient availability is one of the constraints to crop production on acid soils. Lime requirement for crops grown on acid soils is determined by the quality of liming material, status of soil fertility, crop species and varieties, crop management practices, and economic considerations. A considerable loss in growth and yield of many food and fodder crops is caused by root-parasitic flowering plants. Globally, Striga and Orobanche have a greater impact on human welfare than any other parasitic angiosperms because their hosts are subsistence crops in areas marginal for agriculture. In irrigated agriculture, efficient water management is an important element. Such practices can help bust sustainable production and maintain farm profitability in which there is limited water resource.

\section{Introduction}

The current, during 2015 demographic year, Ethiopian population of 99.39 million is expected to increase at rate $2.5 \%$ annually (UNDESA, 2015). Ethiopia is also one of the countries which are on the verge of development and the food consumption pattern is expected to increase in the near future (Gebrehiwot and Gebrewahid, 2016). Moreover, in the arid and semi-arid zones, which count for significant portion of the country's cultivable land, agriculture is normally impossible without an irrigation system (Schultz, 2001). It is also believed that the development of irrigated agriculture is necessary for fulfilling the rising food requirements of the burgeoning global population (Singh, 2015). However, the intensification of irrigated agriculture causes the twin menace of waterlogging and soil salinization in arid and semiarid regions where more than $75 \%$ of the world's population lives (Singh, 2015). The increased pressure from salinity and waterlogging cause decline in growth rates of some crops which make the crop production hikes insufficient to meet projected food demands (Wichelns and Qadir, 2015). In Ethiopia, despite significant efforts by the government and other stakeholders, water management in irrigated areas is hampered by constraints in policy, institutions, technologies, capacity, infrastructure, and markets (Awulachew et al., 2010). As reported by Ruffeis et al. (2008) most of the established or proposed irrigation schemes are found in the arid and semi-arid lowlands of Ethiopian's major river basins. The challenge for sustainable irrigation is more substantial in these arid and semi-arid regions, where large production areas are impacted by soil salinity, inadequate subsurface drainage, and waterlogging (Wichelns and Qadir, 2015). As a result, while the potential benefits of irrigation are great, the actual achievement in many irrigated areas of the country is substantially less than the potential due to poor water management leading to waterlogging, salinity and related problem (Hordofa et al., 2008).

Yet, the attention given to drainage in developing countries have been limited mainly due to its cost and delayed recognition that poor drainage is an important constraint on yield once irrigation supply problems are resolved (Abbott and Leeds-Harrison, 1998). Without any exception, the Ethiopian irrigated agriculture has not been supported by appropriate modern drainage systems. 
Considering the potential harm that can arise when drainage systems are not installed in a timely manner, Wichelns and Qadir (2015) recommended the need to develop drainage solutions concurrent with irrigation schemes. It is also strongly recommended, always to include the costs of an ultimately necessary drainage system in the projects costs of an irrigation system (Datta and Jong, 2002). In Ethiopia, efforts have been made to introduce an improved drainage technology called Broad Bed and Furrow (BBF); albeit its utilization has been by far less than the expectation. Many research findings, however, reported a positive evaluation with regard to the effectiveness of drainage at different levels which can be considered as a driving force for integrating irrigation with appropriate drainage system in the country.

Soil acidity is among the major land degradation problems, which affects $\sim 50 \%$ of the world's potentially arable soils (Kochian et al., 2004). Naturally, soils tend to become acid because of the leaching mechanism of carbonic acid $\left(\mathrm{CO}_{2}\right.$ dissolved in rainwater). Acidification continues until a balance is reached between removal and replacement. Basic cations such as calcium $(\mathrm{Ca})$ and magnesium $(\mathrm{Mg})$ are removed through leaching and crop harvest but at the same time these bases are replaced due to organic matter decomposition and from the weathering of minerals (Abebe, 2007; Sanchez, 1977). Geologically, soil acidity increases as rainfall increases. The availability of micronutrients such as Aluminum (Al), manganese (Mn) and iron $(\mathrm{Fe})$ increases as the $\mathrm{pH}$ decreases. The major causes for soils to become acid are high rainfall and leaching, acidic parent material, organic matter decay, and harvest of high yielding crops (Eswaran et al., 1997b; Von Uexküll and Mutert, 1995). Crop management practices, removal of organic matter, continuous application of acid forming fertilizers and contact exchange between exchangeable hydrogen on root surfaces and the bases in exchangeable form on soils, microbial production of nitric and sulfuric acids can also contribute to soil acidity (Behera and Shukla, 2015; Fageria and Nascente, 2014). Roem and Berendse (2000) indicated that increasing N: P and $\mathrm{N}$ : $\mathrm{K}$ ratios appear to have adverse effects on the abundance of endangered species owing to soil acidification. The management of acid soils is the major problem area in the humid tropics. The identification and description of a problem area, however, does not justify a major research effort. An in-depth analysis of our present knowledge of soil processes related to soil acidity and the management of acid soils is required (Fageria and Baligar, 2008). Although many research related to the management of acid soils have been conducted in South America , Africa (Eswaran et al., 1997a; Tully et al., 2015), Asia and Australia (Bai et al., 2008; Eswaran et al., 1997b), there is no more detailed information and understanding of the problem related to the management of acid soils and different management options. The focus of MAS should be developing appropriate technologies for sustainable management of soil and water resources of acid soil agroecosystems. Indiscriminate clearing, inappropriate land use and mismanagement of soil and water resources are degrading the resource base. The loss of top soil means declining soil fertility, deterioration of soil structure and lower productivity (Bronick and Lal, 2005; Lal, 2015).

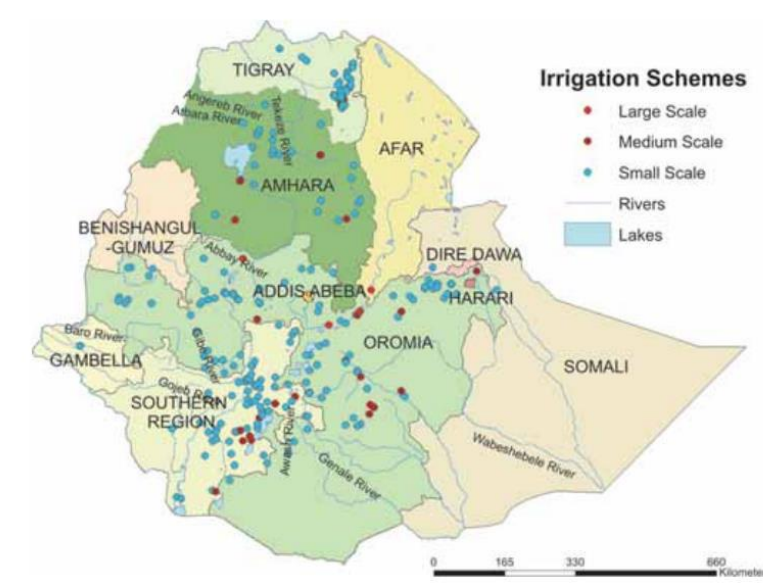

Figure 1 Existing irrigation schemes distributed in the regional states of Ethiopia

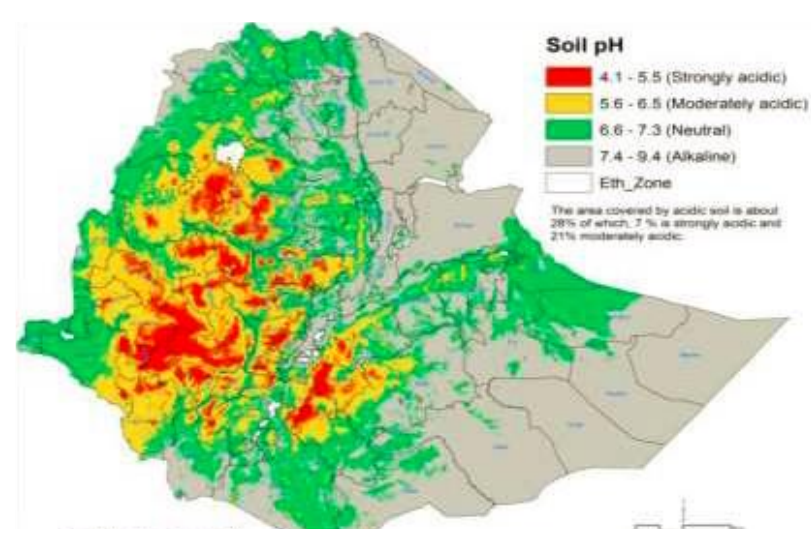

Figure 2 Extent and distribution of soil acidity (ATA, 2014) in Ethiopia

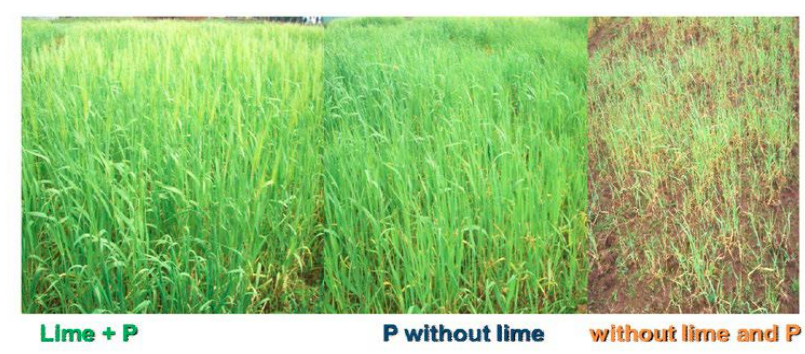

Figure 3 Growth of barley plants with lime and P, with $\mathrm{P}$ alone and without lime in acidic soils of Welmera and Endibir Source: Getachew et al., 2019

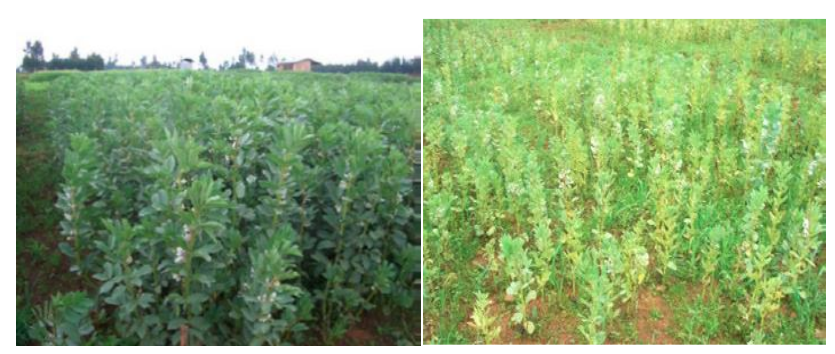

Figure 4 The growth of faba bean under limed and unlimed condition on acidic soils Welmera Woreda (Source: Getachew et al., 2019) 
Orobanchaceae (Aeginetia, Orobanche, broomrape) and Scrophulariaceae (Alectra, Striga, witchweed) are considered to be among the most serious agricultural pests of economic importance in many parts of the world. The genus Striga includes about 40 species, of which 11 species are parasites on agricultural crops. The genus Orobanche has more than 100 species but only seven are considered as economically significant (Parker and Riches, 1993; Raynal-Roques, 1996).

Agriculture sector is facing increasing challenges in the face of changing climate, rapid population growth, increasing salinity accumulation, land degradation, decreasing availability of land, waterlogging, parasitic weeds, and competition for scarce water resources (Figure 1, 2, 3 and 4). This paper reviews important technical issues related to drainage problems in Ethiopia, notably waterlogging, salinization, soil acidity, parasitic weeds, irrigation scheduling, and their consequences on the productivity of irrigated agriculture. It also briefly discusses the land reclamation and efficiently water using techniques practiced by the farmers, the government and non-governmental organizations (NGOs) and their effectiveness in controlling waterlogging and salinity.

\section{Material and Method}

A literature search was conducted through the Web of Science (apps.webofknowledge.com), Google Scholar (scholar.google.com), AGRIS (agris.fao.org), Research Gate (https://www.researchgate.net), the Ethiopian Society of Soil Science (www.esss.org.et), and libraries of the Ethiopian Institute of Agricultural Research (EIAR) and National Soils Research Center. We searched the literature published 2006 up to 2017, using "soil acidity", "management of soil acidity", "integrated soil fertility management", and "liming" , " waterlogging", "management of waterlogging", "parasitic weeds", "managements of parasitic weeds" , " soil salinity", "integrated soil salinity management", and "irrigation scheduling" as key terms. Although over 176 papers were retrieved, we focused on those reporting empirical results on soil acidity, waterlogging, soil salinity, parasitic weeds, irrigation scheduling, and their managements, and thus about 60 publications were used to develop this review paper. Individual articles from the collected literature were grouped with respect to research objectives and experimental types. Research objectives were further sub-categorized into articles focusing on organic and inorganic nutrient sources, including lime, and other management practices such as acid tolerant crop species and varieties. Crops tested for soil acidity tolerance in the field were cereals (grain crops, such as wheat, maize, and barley), food legumes (faba bean and soybean), and root crops (potato), effect of irrigation scheduling on crop production, parasitic weeds infestations and their managements.

\section{Results and Discussions}

\section{Waterlogging on Vertisols}

Ethiopia ranks third in Vertisols abundance in Africa after Sudan and Chad (Kebede and Bekelle, 2008). Vertisols cover a total of 12.6 million ha (10.3 percent) of the soils in Ethiopia of which more than 60 percent is in the highlands where traditional smallholder mixed farming is practiced (Jutzi, 1990). They are most frequent on the 0-2 percent slope range, and are usually found in landscapes of restricted drainage (Debele, 1985). The main limitation to the utilization of Vertisols for crop production is their workability and land preparation problems at low moisture content for tillage and their sticky nature at high moisture levels (El Wakeel and Astatke, 1996; Erkossa et al., 2004). The pores of clay soils are less connected than those of sandier soils (Jackson, 2012). As a result, they have very slow internal drainage with daily infiltration rates between 2.5 and $6.0 \mathrm{~cm}$ which poses a major problem for water management (El Wakeel and Astatke, 1996; Erkossa et al., 2004). Because of limited internal drainage, in Ethiopia, the tremendous potential of Vertisols for crop production is severely constrained by waterlogging leading to yield reduction (Keneni et al., 2002).

Waterlogging affects plant growth by reducing soil aeration around the root zone (Singh, 2015). Due to the occurrence of seasonal waterlogging during the main rainy season, early planting is prohibited with traditional management system in the north central highlands which in its turn reduce the length of the growing cycle (Erkossa et al., 2004; Kebede and Bekelle, 2008). Similarly, the Wonji-Shoa Sugar Estate, one of the large scale irrigation systems within the Upper Awash River Basin of Ethiopia with nearly half of its plantation area covered by heavy black clay soils, has been experiencing large yield reductions (approximately $45 \%$ of the created potential of the 1960s) in recent times mostly because of waterlogging and its allied problems (Dinka and Ndambuki 2014).

Despite the great potential of improved Vertisols management for increased food and feed production, the potentially productive Vertisols located on gentle slopes continue to be underutilized because of socio-technical problems associated with their management (Erkossa et al., 2004). This tends crops to have limited yield potential and little ability to respond to fertilizers. Under traditional management systems, yield from these soils is far below the potential (Erkossa et al., 2004). Considering their large moisture-holding capacity and relatively high fertility, Vertisols are capable of producing many times more food and livestock feed than they do today in the Ethiopian Highlands. Techniques to modify land features and soil properties are needed in order to create a favourable environment for seedling establishment and crop growth (El Wakeel and Astatke, 1996). For instance, the adoption of the BBF land management system could facilitate increases in yields of both grain and straw from the major crops compared with the yield from traditional cultivation in flat beds.

\section{Salt Affected Soils and Salinity}

Over 11 million ha of land in Ethiopia are known to be salt affected (Ruffeis et al., 2008; Taddese, 2001). These salt-affected soils are prevalent in Rift Valley, the arid and semi-arid lowlands and other areas that are characterized by higher evapotranspiration rates (Asfaw and Itanna, 2009; Dubale, 2002; Geressu and Gezaghegne, 2008). To this effect, salinization has been a major constraint to the irrigated agriculture of the country. The Awash basin can be considered as a typical example where salinization has been a critical problem in its many large and medium scale irrigation schemes including the Amibara irrigation project in the Middle Awash and theMetahara sugar plantation in the Upper Awash (Ayenew, 2007). Large areas of the 
middle and lower parts of the basin are also saline or sodic or in saline or sodic phase and thus potentially exposed to salinization and sodicity (EIAR 2006) as cited in (Ruffeis et al., 2008). Salinization is more spreading in irrigated lands because of inappropriate management of irrigation and drainage. Salt-affected lands had increased from $6 \%$ to $16 \%$ of the total land area of Ethiopia (Abraha and Yohannes, 2013). As reported by Zewdu et al. (2014), in Sego Irrigation Farm in southern Ethiopia, the coverage of moderately and strongly saline areas has increased at an average annual rate of $4.1 \%$ and $5.5 \%$ respectively from 1984 to 2010. Moreover, 44 million ha $(36 \%$ of the country's total land area) is potentially susceptible to salinity problems (Hawando, 1994).

The main sources and/or causes of salinity are shallow groundwater tables and natural saline seeps. Poor drainage and lack of appropriate irrigation water management is also known to facilitate secondary salinization (Abebe et al., 2015). Improperly planned irrigation projects not supported by improved irrigation and drainage management technologies had invited serious degradation causing salinity and sodicity problems in the Awash basin which accounts for about one-third of total irrigated area of the country (Dubale et al., 2002; Ruffeis et al., 2008). This high salinity problem is also related to uncontrolled irrigation practice and lack of knowledge on crop water requirements and water management leading to increased saline groundwater level or capillary rise (Ayenew, 2007). Discharge to the groundwater by surplus irrigation water has caused a rise in the water table $(0.5 \mathrm{~m} /$ year $)$ in Middle Awash irrigated field and problems with secondary salinity in surface and sub- surface soil horizons (Taddese et al., 2003). Another source of salinity for rivers and other sources of irrigation water is attributed to salts of marine origin. During the rainy season, water quality of River Wabishebele for irrigation deteriorates as a result of very high flooding which dissolves soluble salts from loose marine origin along its course (Taddese, 2001). Climate is also a key factor in the salinization process. The high temperature of the Middle Awash (annual average $26.7^{\circ} \mathrm{C}$ ) and low annual rainfall $(500 \mathrm{~mm})$ and the high free evaporation of water have aggravated the salinization process (Ayenew, 2007; Bekele, 2005).

Salt affected soils are characterized with excess concentrations of calcium $(\mathrm{Ca}+)$, sodium $(\mathrm{Na}+)$ and chloride $(\mathrm{Cl}-)$ which are easily soluble (Bekele 2005). This has an adverse effect on seedling growth of several crops, by creating an osmotic potential in the rhizosphere of the plant which inhibits the absorption of water or creates toxic effect due to $\mathrm{Na}+$ and $\mathrm{Cl}-$ to the roots and the whole crop (Abraha and Yohannes, 2013; Singh, 2015). Osmotic potential is the potential of water molecules to move from a high solutes concentrated solution to a less solutes concentrated solution across a semi permeable membrane. When salt affected soils are intensively cultivated without proper caution for the gradual accumulation of salts and soluble substances, it may result in severe land degradation. Poor irrigation water management and operation coupled with the absence of drainage system can cause groundwater rise (waterlogging), salinization and considerable losses in crop yields which ultimately led to abandonment of substantial irrigable areas. The problems of salinity and waterlogging persist in many regions where farmers apply excessive irrigation water, and where farmers and irrigation departments fail to invest in adequate drainage solutions (Wichelns and Qadir, 2015). For example, soil salinity has caused abandonment of banana plantation in Amibara, cotton plantation in Melka Sedi and nearly 30 ha of farmland in Metahara sugar plantation due to a progressive rise of groundwater as a result of over irrigation (Abebe et al., 2015; Abegaz, 1996; Ayenew, 2007). Asfaw and Itanna (2009) also indicates that of the entire Abaya State Farm, 30\% has already been salt affected.

\section{Drainage as Land Reclamation Technique}

The traditional management of waterlogging on Vertisols in the Ethiopian Highlands varies from one place to another depending on the amount and duration of rainfall, slope, farm size and the extent of the drainage problem (El Wakeel and Astatke, 1996). Among the most common farmers' practices has been the use of a local plough to construct narrow ridges and furrows at sowing so that the crops grow on ridges while the excess water drains through the furrows. Similarly, broad beds and furrows of about $120 \mathrm{~cm}$ width entirely made by hand are utilized (Mesfin and Jutzi, 1986). The other forms of Farmer's strategy to utilize Vertisols has always been to plant late in the wet season, which means harvesting a single crop and leaving the land under-utilized or idle (Mamo et al., 1993). Local farmers in Delanta Dawunt woreda traditionally grow relatively waterlogging resistant crop, Enzosh Synde, a 'local wheat variety' which also tolerates frost (Kebede and Bekelle, 2008). On the other hand, to cope with the situation, farmers traditionally plant low-yielding crops adapted to the poor internal drainage or crops that perform on residual moisture after the main rains (Erkossa et al., 2004). However, all these traditional management practices generally result in low yields (El Wakeel and Astatke, 1996). Thus, to achieve productive and sustainable irrigation, farmers must be advised to implement the right mix of agronomic practices, in conjunction with wise water use and careful management of shallow water tables and entire irrigation systems (Wichelns and Qadir 2015).

Land shaping techniques, surface and sub-surface drainage, and management of soil through improved tillage are among the options to control waterlogging, improve drainage and ensure sustained productivity of soil (El Wakeel and Astatke, 1996; Erkossa et al., 2004). Despite their better drainage problems control ability thereby improving crop yields, land modification techniques like camber beds are found inappropriate, financially, for the smallholder farmers in Ethiopian due to the need of tractors for the land shaping (El Wakeel and Astatke, 1996).

A surface drainage method called broad bed and furrow (BBF), made by animal-drawn implement (the broad-bed maker) developed by the International Livestock Research Institute (ILRI) and its research partners, has been adopted in many parts of Ethiopian covered with Vertisols (El Wakeel and Astatke, 1996; Erkossa et al., 2004). The potential impact of this low input technology on food production in Ethiopia, which has nearly 8 million ha of Vertisols in the high-rainfall highland areas, is considerable (Jutzi et al., 1987). It enables management of excess water for increased production (Asamenew et al., 1993; Asamenew et al., 1988; Kebede and Bekelle, 2008). It was also reported in many literatures (Erkossa et al., 2004; Jutzi et al., 1987) that the broad bed and furrow 
(BBF) technology facilitates weed control and enable crops to utilize the whole growing period as it gives the opportunity to practice early planting, which in turn results in better crop growth (Table 9). Where rainfall is inadequate or erratic during the year, the furrows between ridges can conserve moisture, which is another strategy for growing crops on Vertisols (El Wakeel and Astatke, 1996). Moreover, provided that water harvesting mechanisms are developed to collect the excess water drained due to $\mathrm{BBF}$ from the field, double cropping is a possible option
(Erkossa et al., 2004). Substantial increases in grain and biomass yields due to enhanced surface drainage from the application of the broad bed and furrow (BBF) land management system technology were recorded in many parts the country. Research findings from different parts of Ethiopia in different crops are summarized in the Table 1 below. More interestingly, as described by Keneni et al. (2002), the integration of improved drainage using BBF with the highest yielding genotypes can enable doubling of crop yield of a farm (Table 9).

Table 1 Effect of lime on soil chemical properties

\begin{tabular}{|c|c|c|c|c|c|c|c|c|c|}
\hline \multirow{2}{*}{$\mathrm{T}$} & \multirow{2}{*}{$\mathrm{pH}$} & \multicolumn{2}{|c|}{$\operatorname{cmol}(+) \mathrm{kg}^{-1}$} & \multicolumn{6}{|c|}{ Concentration $\left(\mathrm{mg} \mathrm{kg}^{-1}\right)$} \\
\hline & & $\mathrm{CEC}$ & $\mathrm{Al}$ & $\mathrm{EA}^{1}$ & $\mathrm{P}$ & $\mathrm{Fe}$ & $\mathrm{Mn}$ & $\mathrm{Cu}$ & $\mathrm{Zn}$ \\
\hline 0 & $5.03^{\mathrm{d}}$ & $19.18^{\mathrm{d}}$ & $0.68^{\mathrm{a}}$ & $0.97^{\mathrm{a}}$ & $5.36^{\mathrm{b}}$ & $41.96^{\mathrm{a}}$ & $70.3^{\mathrm{a}}$ & $0.37^{\mathrm{d}}$ & $11.67^{\mathrm{a}}$ \\
\hline 1.25 & $5.64^{\mathrm{c}}$ & $25.21^{\mathrm{c}}$ & $0.56^{\mathrm{b}}$ & $0.75^{b}$ & $6.70^{\mathrm{a}}$ & $33.77^{\mathrm{b}}$ & $58.4^{\mathrm{b}}$ & $0.77^{\mathrm{b}}$ & $11.19^{b}$ \\
\hline 2.50 & $6.14^{b}$ & $31.49^{b}$ & $0.33^{\mathrm{c}}$ & $0.51^{\mathrm{c}}$ & $7.04^{\mathrm{a}}$ & $25.04^{b}$ & $46.0^{\mathrm{c}}$ & $0.99^{\mathrm{a}}$ & $9.78^{\mathrm{c}}$ \\
\hline 3.75 & $6.72^{\mathrm{a}}$ & $33.34^{\mathrm{a}}$ & $0.24^{\mathrm{c}}$ & $0.36^{\mathrm{c}}$ & $6.67^{\mathrm{a}}$ & $19.01^{\mathrm{c}}$ & $34.5^{\mathrm{d}}$ & $0.65^{\mathrm{c}}$ & $9.75^{c}$ \\
\hline LSD (0.05) & 0.014 & 0.738 & 0.13 & 0.21 & 0.94 & 0.390 & 4.52 & 0.059 & 0.138 \\
\hline $\mathrm{CV}(\%)$ & 3.01 & 6.24 & 8.12 & 6.43 & 2.04 & 11.56 & 14.73 & 10.11 & 12.38 \\
\hline
\end{tabular}

${ }^{1}$ EA: Exchangeable acidity; T: Treatment (lime t ha ${ }^{-1}$ ), Source: Buni (2014).

Table 2: Estimation of lime requirements for different soil $\mathrm{pH}$ ranges using BC method

\begin{tabular}{|c|c|c|c|}
\hline \multirow{3}{*}{$\begin{array}{l}\mathrm{pH} \text { ranges } \\
\text { used in the } \\
\text { curve }\end{array}$} & \multirow{3}{*}{$\begin{array}{lcc}\text { Curve } & \text { BC } & \text { BC } \\
\text { slopes }(\mathrm{g} / 100 \text { soil }) & \left(\mathrm{kg} \mathrm{ha}^{-1}\right)\end{array}$} & \multirow{3}{*}{$\begin{array}{c}\text { Remark or recommendation on the use } \\
\text { of } \mathrm{BC} \text { values }\end{array}$} & $\begin{array}{l}\text { Examples of lime rates to raise a } \\
\text { given soil } \mathrm{pH} \text { to target } \mathrm{pH}\end{array}$ \\
\hline & & & $\mathrm{pH}$ range \\
\hline & & & Initial Target \\
\hline
\end{tabular}

Estimation of BC values and lime rates (kg/ha) for soils with $\mathrm{pH}$ between 5.0 and 5.6 to raise the $\mathrm{pH}$ between 6.0 and 6.5

\begin{tabular}{l|llllrrr}
\hline $5.17-6.12$ & 31.61 & 0.0316 & 644 & $\begin{array}{l}\text { For soils with pH 5.0-5.6 } \\
\text { Acceptable, but less economical for } \\
\text { one time use }\end{array}$ & 5.2 & 6.0 & 530 \\
$5.17-6.4$ & 24.87 & 0.0402 & 844 & 6.4 & 1010 \\
\hline
\end{tabular}

Estimation of $\mathrm{BC}$ values and lime rates $\left(\mathrm{kg} \mathrm{ha}^{-1}\right)$ for soils with $\mathrm{pH}$ between 4.5 and 5.0 to raise the $\mathrm{pH}$ between 6.0 and 6.5

\begin{tabular}{|c|c|c|c|c|c|c|c|}
\hline $4.65-6.0$ & 11.21 & 0.0892 & 1873 & For soils above $\mathrm{pH} 4.6$ & 4.8 & 6.0 & 2250 \\
\hline $4.65-6.30$ & 8.26 & 0.1211 & 2544 & Expensive & 4.8 & 6.3 & 3820 \\
\hline $4.63-5.61$ & 12.24 & 0.0817 & 1716 & $\begin{array}{l}\text { Cheaper for one time use, maybe with } \\
\text { insignificant yield reduction } \\
\text { The rate is not recommended for split } \\
\text { or localized application. }\end{array}$ & 4.8 & 5.6 & 13 \\
\hline
\end{tabular}

Estimation of $\mathrm{BC}$ values and lime rates $\left(\mathrm{kg} \mathrm{ha}^{-1}\right)$ for soils with $\mathrm{pH}$ between 3.8 and 4.5 to raise the $\mathrm{pH}$ between 6.0 and 6.5

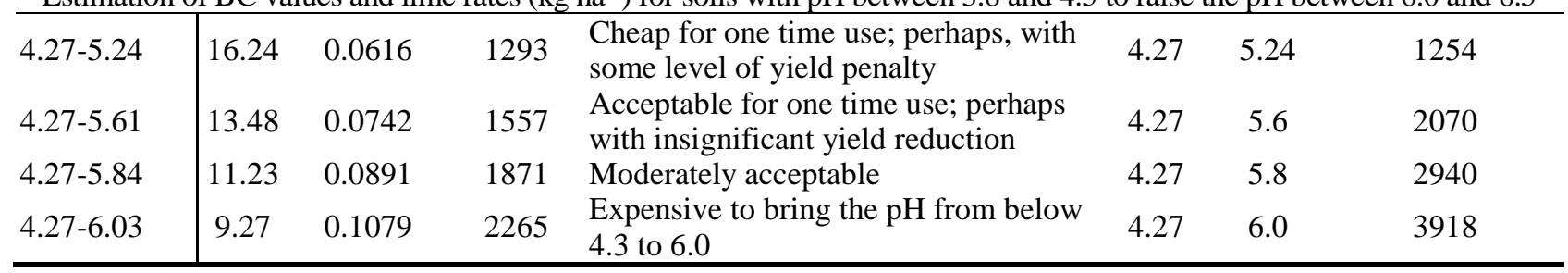

Source: Getachew et al., 2019

Despite the potentially misleading opinion that "drainage is prohibitively expensive", implementing drainage measures may be justified, even in an area where land productivity is only moderately affected by soil salinity (Datta and Jong, 2002). Yet, besides installation of drainage systems to intercept deep percolation of the excess water, other more cost-effective engineering or agronomic measures need to be considered. For instance, efficient farm-level water management is essential to minimize the size and cost of regional drainage efforts (Wichelns and Qadir, 2015). Triantafilis et al. (2002) as cite in Gadissa and Chemeda (2009) reported that general improvements in salinity control can be made from maximizing on farm irrigation efficiency. Evidently, irrigation water must be used sparingly, particularly in arid and semi-arid areas, as each unit of irrigation water adds salt that contributes to higher salinity levels in surface streams and ground-water (Wichelns and Qadir, 2015). Introduction of salt tolerant crops and other crop management techniques can also help control salinity in an economical and efficient way (Asfaw and Itanna, 2009). Apart from economic reasons, also environmental and social considerations ought to play a part in the decision making on drainage development (Datta and Jong, 2002). This is because intensification of irrigation for increased production has resulted in serious environmental concerns and pose difficult problems in many parts of the world with regard to irrigation sustainability (Rhoades, 1997) as cited in (Howell, 2001). Obviously, irrigation and drainage schemes must account for water quality impacts, and farmers must be motivated to irrigate efficiently, with minimum leaching fractions (Ayars and Hanson, 2014). 
Table 3 Common liming materials and their calcium carbonate equivalent

\begin{tabular}{l|lc}
\hline \multicolumn{1}{c|}{ Name Calcitic limestone } & \multicolumn{1}{|c}{ Chemical formula $\mathrm{CaCO}_{3}$} & Equivalent $\left(\% \mathrm{CaCO}_{3}\right) 90-100$ \\
\hline Dolomitic limestone & $\mathrm{CaCO}+\mathrm{MgCO}_{3}$ & $95-110$ \\
Oxide/burned lime & $\mathrm{CaO}$ & $150-175$ \\
Hydrated lime & $\mathrm{Ca}(\mathrm{OH})_{2}$ & $120-135$ \\
Ground shells & $\mathrm{CaCO}$ & $80-95$ \\
Basic slag & $\mathrm{CaSiO}$ & $50-80$ \\
Wood ashes & Oxides and hydroxides & $30-70$ \\
\hline
\end{tabular}

Source: Michael (2000)

Table 4 Effect of lime and other soil fertility management on crop yield and soil properties

\begin{tabular}{|c|c|c|c|c|c|c|}
\hline \multirow[b]{2}{*}{ Crop } & \multicolumn{2}{|c|}{ Treatment } & \multicolumn{2}{|c|}{ Yield } & \multirow{2}{*}{$\begin{array}{l}\text { Effect on soil properties and } \\
\text { nutrient uptake }\end{array}$} & \multirow[b]{2}{*}{ Source } \\
\hline & $\begin{array}{l}\text { Manure } \\
\left(\mathrm{t} \mathrm{ha}^{-1}\right)\end{array}$ & $\begin{array}{l}\text { Lime } \\
\left(\mathrm{t} \mathrm{ha}^{-1}\right)\end{array}$ & $\left(\mathrm{t} \mathrm{ha}^{-1}\right)$ & $\begin{array}{l}\% \text { increase } \\
\text { over control }\end{array}$ & & \\
\hline Wheat & $0-5.0$ & $0.0-2.20$ & $0.90-2.69$ & 94-199 & & $\begin{array}{l}\text { Asrat et al. } \\
\text { (2014) }\end{array}$ \\
\hline \multirow[t]{2}{*}{ Wheat } & & $0-10$ & $2.44-4.27$ & $34-75$ & $\begin{array}{l}\text { Liming improved soil } \mathrm{pH} \\
\text { and plant } \mathrm{P} \text { uptake. }\end{array}$ & $\begin{array}{c}\text { Bore and } \\
\text { Bedadi (2016) }\end{array}$ \\
\hline & $\begin{array}{c}\mathrm{N} / \mathrm{P} / \mathrm{K} \\
\left(\mathrm{kg} \mathrm{ha}^{-1}\right)\end{array}$ & $\begin{array}{l}\text { Lime } \\
\left(\mathrm{t} \mathrm{ha}^{-1}\right)\end{array}$ & $\begin{array}{l}\text { Yield } \\
\left(\mathrm{t} \mathrm{ha}^{-1}\right)\end{array}$ & $\begin{array}{c}\% \text { increase } \\
\text { over control }\end{array}$ & & \\
\hline Tef & $0-46 / 0-26 / 0$ & $0.00-2.00$ & $0.82-2.88$ & $99-252$ & $\begin{array}{l}\text { Liming increased soil } \mathrm{pH} \\
\text { from } 5.38 \text { to } 6.17 \text { and } \mathrm{CEC} \\
\text { from } 14.8-20.7\end{array}$ & $\begin{array}{l}\text { Abewa et al. } \\
\qquad(2014)\end{array}$ \\
\hline Soybean & $18 / 20 / 0$ & $0.00-3.75$ & & & $\begin{array}{l}\text { Increased soil } \mathrm{pH} \text { from } 5.03- \\
6.72 \text {, and reduced } \mathrm{Al}^{3+} \text { from } \\
0.68-0.36 \mathrm{cmol} \mathrm{kg}^{-1}\end{array}$ & Buni (2014) \\
\hline Soybean & $18 / 20 / 0$ & $0.00-2.60$ & $1.58-2.31$ & $28.9-45.9$ & $\begin{array}{l}\text { Increased nodule dry weight } \\
\text { by } 100 \% \text {. }\end{array}$ & $\begin{array}{l}\text { Bekere et al. } \\
\qquad(2013)\end{array}$ \\
\hline Barley & $50 / 0-30 / 0$ & $0.00-2.20$ & $2.54-4.56$ & $52-81$ & $\begin{array}{l}\text { Lime reduced } \mathrm{Al}^{3+} \text { by } 0.88- \\
1.19 \text { meq } 100 \mathrm{~g}^{-1} \text { soil, and } \\
\text { raised soil } \mathrm{pH} \text { by } 0.48-1.1 \\
\text { units. }\end{array}$ & $\begin{array}{l}\text { Desalegn et al. } \\
\quad \text { (2017) }\end{array}$ \\
\hline Barley & $145 / 00 / 00$ & $0.00-7.00$ & $2.52-4.24$ & $15-68$ & $\begin{array}{l}\text { Lime increased } \mathrm{pH} \text { in the } \\
\text { surface } 15 \mathrm{~cm} \text {, but reduced } \\
\mathrm{Al}^{3+} \text { only in the } 0-5-\mathrm{cm} \\
\text { layer. }\end{array}$ & $\begin{array}{l}\text { Tabitha et al. } \\
\qquad(2008)\end{array}$ \\
\hline Barley & $41 / 20 / 0$ & $0-4.5$ & $1.28-1.83$ & $4.0-41.2$ & $\begin{array}{l}\text { Liming increased soil } \mathrm{pH} \\
\text { from } 4.53-5.61 \text { and reduced } \\
\text { EA from } 2.2-0.23 \mathrm{cmol} \mathrm{kg}^{-1}\end{array}$ & Beyene (1987) \\
\hline Oat & - & $0.0-2.0$ & $0.96-1.48$ & $5-54$ & $\begin{array}{l}\text { Liming reduced the } \mathrm{H}^{+} \text {and } \\
\mathrm{Al}^{3+} \text { contents to a depth of } \\
0.60 \mathrm{~m} \text {. }\end{array}$ & $\begin{array}{c}\text { da Costa and } \\
\text { Crusciol (2016) }\end{array}$ \\
\hline Maize & $60 / 26 / 0$ & $0-2.0$ & $1.77-4.99$ & $111-182$ & $\begin{array}{l}\text { Liming increased soil } \mathrm{pH} \\
\text { from } 4.92-5.46 \text { and reduced } \\
\text { EA from } 0.25-0.10 \mathrm{cmol} \mathrm{kg}^{-1} \text {. }\end{array}$ & $\begin{array}{l}\text { Opala et al. } \\
\text { (2018) }\end{array}$ \\
\hline Faba bean & $18 / 20 / 0$ & $0.0-5.0$ & $0.81-1.47$ & $45-53$ & $\begin{array}{l}\text { Liming increased soil } \mathrm{pH} \\
\text { from } 5.10-5.91 \text { and reduced } \\
\text { EA from } 1.31-0.12 \mathrm{cmol} \mathrm{kg}^{-1} \text {. }\end{array}$ & $\begin{array}{l}\text { Agegnehu et al. } \\
\text { (2006) }\end{array}$ \\
\hline $\begin{array}{l}\text { Mucuna } \\
\text { flagellipes }\end{array}$ & - & $0.0-4.0$ & $1.39-2.82$ & $45-103$ & $\begin{array}{l}\text { Liming increased soil } \mathrm{pH} \\
\text { from } 4.32-6.11 \text {. }\end{array}$ & $\begin{array}{c}\text { Agba et al. } \\
\text { (2017) }\end{array}$ \\
\hline \multirow[t]{2}{*}{ Potato } & $\begin{array}{c}0 / 0 / 0 /- \\
10 / 40 / 100\end{array}$ & $0.0-3.5$ & $\begin{array}{l}10.03- \\
30.67\end{array}$ & $59-332$ & $\begin{array}{l}\text { Liming increased soil } \mathrm{pH} \\
\text { from 4.8-5.47. }\end{array}$ & $\begin{array}{l}\text { Haile and Boke } \\
\qquad(2009)\end{array}$ \\
\hline & $\begin{array}{c}\mathrm{NPK} \\
\left(\mathrm{kg} \mathrm{ha}^{-1}\right)\end{array}$ & $\begin{array}{l}\text { FYM } \\
\left(\mathrm{t} \mathrm{ha}^{-1}\right)\end{array}$ & $\begin{array}{l}\text { Yield } \\
\left(\mathrm{t} \mathrm{ha}^{-1}\right)\end{array}$ & $\begin{array}{c}\% \text { increase } \\
\text { over control }\end{array}$ & & \\
\hline Faba bean & $18 / 0-52 / 0$ & $0.0-8.0$ & $0.99-2.21$ & $42-123$ & $\begin{array}{l}\text { Addition of FYM increased } \\
\text { soil pH from } 4.51-5.22, \mathrm{~N}, \\
\mathrm{P} \text {, and exchangeable cations. }\end{array}$ & $\begin{array}{l}\text { Agegnehu and } \\
\text { Bekele (2005b) }\end{array}$ \\
\hline Potato & $\begin{array}{c}0 / 0 / 0 /- \\
10 / 40 / 100\end{array}$ & $0-20$ & $17-54$ & $134-217$ & & $\begin{array}{l}\text { Haile and Boke } \\
\qquad(2011)\end{array}$ \\
\hline
\end{tabular}

Source: Getachew et al., 2019 


\section{Yield}

Effects of Soil Acidity on Nutrient Availability and Crop

The importance of indigenous practice in Ethiopian community is critical to farmers' livelihoods and environmental conservation. The local farmers were used various indigenous practices to harness the unfavourable environmental conditions. The farmers were living in highland (Dega) agro-ecological climatic zone heavily depending on local knowledge practices to sustain their livelihoods in unfavourable environment. More uniquely, the highland area of Ethiopia is highly and adversely affected by soil acidity. It is critical agricultural problems in this agro-climatic zone. Particularly the farmers where living in western oromia of Ethiopia were adversely affected with soil acidity and associated soil quality problems. The indigenous farmers were struggling by using their consistence ecological knowledge to harness adverse environmental problems. To avert such farming problem, the farmers of the study area have used various traditional practices and local adapted resilient approaches. This environmental friendly practices were includes the traditional soil acidity amendment of keeping livestock's for at least a week in same square fence throughout the nights for their manure and compost production and application knowledge of farmers to enhance farm productivities and to amend soil quality. The system of keeping livestock's for at least a week in same square fence throughout the night for their manure is called mona. Most of all, this system is one of environmental resilient and local adapted indigenous practices used by farmers to amend acidic soil with organic manure for crop productivity and to improve soil quality. The farmers were described that; the 'mona' is bedding or sleeping places for domestic animals (particularly for cattle and horses). Factually, 'mona' is encircled fences where constructed from bamboo plant near to the farmer's house or farm fields. The main intention of 'mona' building near the houses and farm fields is to collect animal dung/manure to produce organic fertilizer. The dung/manure is organic and easily available to every farmer's family because of their own cattle in the home.

Table 5 Estimated returns to lime use in wheat cultivation based on experimental results of 2015

\begin{tabular}{|c|c|c|}
\hline Item & Without lime & With lime \\
\hline Lime application $\left(\mathrm{t} \mathrm{ha}^{-1}\right)$ & 0 & 2.2 \\
\hline Grain yield $\left(\mathrm{t} \mathrm{ha}^{-1}\right)$ & 0.9 & 1.98 \\
\hline Adjusted grain yield $\left(\mathrm{t} \mathrm{ha}^{-1}\right)^{1}$ & 0.9 & 1.584 \\
\hline Cost of lime at farm gate (birr) & 0 & 4,400 \\
\hline Labor cost for lime application at birr 50/day) & 0 & 800 \\
\hline Total Cost of lime use (birr ha ${ }^{-1}$ ) & 0 & 5,200 \\
\hline Grain price $\left(\right.$ birr $\mathrm{t}^{-1}$ ) & 11,000 & 11,000 \\
\hline Gross value of output (birr ha" ${ }^{-1}$ ) & 9,900 & 17,424 \\
\hline Net returns to lime use (birr ha-1) & 0 & 7,524 \\
\hline Net added value due to lime use (birr ha ${ }^{-1}$ ) & & 2,324 \\
\hline
\end{tabular}

Note: ${ }^{1}$ The experimental wheat grain yield from lime application is adjusted downwards by $20 \%$ to estimate what a typical farmer would be more likely to obtain under farmer conditions. 1USD = Birr 27.27, Source: Getachew et al., 2019

Table 6 Estimated value added to the Ethiopian economy from lime use under the assumption of a single crop, wheat

\begin{tabular}{|c|c|c|}
\hline \multirow{2}{*}{ Item } & \multicolumn{2}{|c|}{ Year } \\
\hline & 2015 & 2020 \\
\hline Area to be rehabilitated $\left(000^{\prime} \text { ha }\right)^{1}$ & 5.1 & 226 \\
\hline Lime required (000’ ton) & 11.22 & 497.2 \\
\hline Value added to gross national income ('000 birr) & 38,372 & $1,700,424$ \\
\hline Net value added to crop production '000 birr) ${ }^{2}$ & 11,852 & 525,224 \\
\hline
\end{tabular}

${ }^{1}$ Reclamation of acid soil goes as planned by MoANR and reaches 256,000 ha by end of GTP II period., ${ }^{2}$ Values for the year 2015 represents the base scenario while 2020 value refer to end of GTP II, Source: Getachew et al., 2019

The solubility and availability of important nutrients to plants is closely related to the $\mathrm{pH}$ of the soil (Marschner, 2011; Somani, 1996). Soil $\mathrm{pH}$ affects the availability of plant nutrients. Effects of high acidity in a soil are shortage of available $\mathrm{Ca}, \mathrm{P}$ and $\mathrm{Mo}$ on the one hand, and excess of soluble $\mathrm{Al}, \mathrm{Mn}$ and other metallic ions on the other (Agegnehu and Sommer, 2000a; Somani, 1996). Acid soil limits the availability of crucial nutrients such as $\mathrm{P}, \mathrm{K}, \mathrm{Ca}$ and $\mathrm{Mg}$, and affects the movement of soil organisms plants need to stay healthy. If a particular soil is too acidic for plants to grow healthy, it is necessary to raise the $\mathrm{pH}$ by applying an alkaline substance.

Soil acidity and associated low nutrient availability is one of the constraints to crop production on acid soils (Bekele and Hofner, 1993; Beyene, 1987; Mamo and Haque, 1991). If a $\mathrm{pH}$ of a soil is less than 5.5 phosphate can readily be rendered unavailable to plant roots as it is the most immobile of the major plant nutrients (Agegnehu and Sommer, 2000b; Sanchez, 1977), and yields of crops grown in such soils are very low. In soil pH between 5.5 and 7, $\mathrm{P}$ fixation is low and its availability to plants is higher. Toxicity and deficiency of Fe and $\mathrm{Mn}$ may be avoided if the soil reaction is held within a soil $\mathrm{pH}$ range of 5.5 to 7 ; this $\mathrm{pH}$ range seems to promote the most ready availability of plant nutrients (Somani, 1996). The quantity of $\mathrm{P}$ in soil solution needed for optimum growth of crops lies in the range of 0.13 to $1.31 \mathrm{~kg} \mathrm{P} \mathrm{ha}^{-1}$ as growing crops absorb about $0.44 \mathrm{~kg} \mathrm{P} \mathrm{ha}^{-1}$ per day (Lawlor, 2004). The labile fraction in the topsoil layer is in the range of 65 to $218 \mathrm{~kg} \mathrm{P} \mathrm{ha}{ }^{-1}$, which could replenish soil solution $\mathrm{P}$ (Lawlor, 2004). 
Table 7 Crop Water Requirement (CWR) and Irrigation scheduling of maize in main season of irrigation

\begin{tabular}{|c|c|c|c|c|c|c|c|c|c|c|c|c|}
\hline Growing Stage & Days & $\mathrm{Kc}$ & Etc & $\mathrm{I}$ & $\mathrm{N}$ & $\mathrm{G}$ & $\mathrm{F}$ & $\mathrm{T}$ & $\mathrm{E}$ & $\mathrm{R}$ & $\mathrm{A}$ & II \\
\hline Initial & 20 & 0.6 & 18 & 18 & 18.7 & 22.2 & 0.38 & & & & & \\
\hline Development & 35 & 0.75 & 121.3 & 121.3 & 102.9 & 127.8 & 0.75 & & & & & \\
\hline Mid & 40 & 1.2 & 185.2 & 185 & 224.9 & 318.6 & 1.86 & & & & & \\
\hline Late & 30 & 0.85 & 177.6 & 162.4 & 132 & 182.5 & 0.91 & & & & & \\
\hline Total & 125 & & 502.1 & 486.8 & 478.5 & 651.1 & 3.9 & 56.8 & 54 & 2.8 & 445.7 & 14 \\
\hline Planting date $(\mathrm{dd} / \mathrm{mm})$ & & 1-Jan & & Harve & g date & $\mathrm{mm})$ & 5-May & & & & & \\
\hline
\end{tabular}

I: Irri. Req, N: Net irr., G: Gross irr, F: Flow (1/s/ha), T: Total RF, E: Effective RF, R: Rain Loss, A: Actual irrg. Req., II: Irr. Interval days, Source: Tefera and Mitku, 2017

Table 8 Average biomass yield and grain yields of maize

\begin{tabular}{l|cccccc}
\hline \multirow{2}{*}{ Treatments } & \multicolumn{4}{c}{2011} & \multicolumn{2}{c}{2012} \\
\cline { 2 - 7 } & $\mathrm{BM}(\mathrm{kg} / \mathrm{ha})$ & $\mathrm{GY}(\mathrm{kg} / \mathrm{ha})$ & WUE $\left(\mathrm{kg} / \mathrm{m}^{3}\right)$ & $\mathrm{BM}(\mathrm{kg} / \mathrm{ha})$ & $\mathrm{GY}(\mathrm{kg} / \mathrm{ha})$ & $\mathrm{WUE}\left(\mathrm{kg} / \mathrm{m}^{3}\right)$ \\
\hline 1=60\%ASMDL & 11795 & 1822 & 1.417 & 11619 & 2220 & 1.500 \\
2=80\%ASMDL & 8433 & 2753 & 1.970 & 9877 & 2598 & 1.653 \\
3=100\%ASMDL & 11168 & 1916 & 1.027 & 11910 & 1797 & 2.103 \\
4=120\%ASMDL & 11339 & 2690 & 1.297 & 9586 & 1850 & 1.733 \\
5=140\%ASMDL & 16923 & 3777 & 1.273 & 13072 & 2951 & 1.220 \\
CV (\%) & 28.12 & 31.68 & 10.41 & 36.35 & 33.1 & 12.04 \\
LSD@0.05 & 4269.9 & 721.13 & 0.274 & $\mathrm{NS}$ & $\mathrm{NS}$ & 0.372 \\
\hline
\end{tabular}

Note: ASMDL is Available Soil Moisture Depletion Level, BM is average maize biomass kg per hectare, GY is average maize grain yield kg per hectare, and WUE is maize water use efficiency $\mathrm{kg}$ per metrecube., Source: Tefera and Mitku, 2017

Table 9 Crop yield increment as a result of Broad Bed and Furrow (BBF) introduction (Jutzi et al. 1987; Kebede and Bekelle 2008; Keneni et al. 2001; Keneni et al. 2002)

\begin{tabular}{l|lc}
\multicolumn{1}{c|}{ Place where experiment conducted } & \multicolumn{1}{c}{ Type of crop } & $\begin{array}{c}\text { Grain yield increment (\%) compared } \\
\text { with flat seed beds }\end{array}$ \\
\hline Delanta Dawunt woreda, North Wollo & Wheat & 51.4 \\
Debre Zeit & Bread Wheat & 78 \\
& Teff & $25^{*}$ \\
Ginchi, Enewari, Ambo, Sinja and Bichena & Faba bean (Vicia faba L.) & $46-49$ \\
\hline
\end{tabular}

*The lower yield increment is due to the higher relative waterlogging tolerance of teff, Source: Gebrehiwot, 2018

Increased acidity is likely to lead to poor plant growth and water use efficiency because of nutrient deficiencies and imbalance, and or induced $\mathrm{Al}$ and Mn toxicity. High concentration of $\mathrm{Al}$ also affects uptake and translocation of nutrients (especially immobilization of $\mathrm{P}$ in the roots) (Baquy et al., 2017; Fageria and Baligar, 2008), cell division, respiration, nitrogen mobilization and glucose phosphorylation of plants (Fox, 1979; Haynes and Mokolobate, 2001).

Soil acidity, at pH 5.5 or lower, can inhibit the growth of sensitive plant species, though it has little effect on insensitive species even at $\mathrm{pH}$ lower than 4 . This $\mathrm{pH}$ effect is compounded and often surpassed by $\mathrm{Al}$ and $\mathrm{Mn}$ toxicity, Ca and Mo deficiency (Baquy et al., 2017; Fox, 1979; Somani, 1996). Roots are commonly the first organs to show injury owing to acid due to Al toxicity; they become stunted, stubbly. Stunted roots have difficulty of getting immobile nutrients, which are frequently deficient in acid soils. The plant's ability to extract water and nutrients, particularly immobile nutrients such as $\mathrm{P}$, is severely reduced (Fox et al., 1979). Plants are consequently very susceptible to drought and are prone to nutrient deficiencies. The red discolorations often associated with $\mathrm{P}$ deficiency are common, micronutrient deficiency symptoms are frequently observed and, due to the direct antagonistic effect of $\mathrm{Al}$ on $\mathrm{Mg}$ absorption, $\mathrm{Mg}$ deficiency symptoms provide a valuable indicator of acidity problems (Marschner, 2011). Exchangeable Al is the dominant cation associated with soil acidity. The damage of the root growth of sensitive crop species is caused when $\mathrm{Al}$ in the soil solution exceeds $1 \mathrm{mg} \mathrm{kg}$. . This often happens when $60 \%$ or more of the exchangeable capacity of the soil is occupied by Al. Damage may also be caused by Mn, which becomes very soluble at pH less than 5.5 (Somani, 1996).

The management of acid soils should aim at improving the production potential by the addition of amendments to correct the acidity and manipulate the agricultural practices to obtain optimum crop yields. The soil's acid/alkali balance (measured by $\mathrm{pH}$ ) of the soil is very important in maintaining optimum availability of soil nutrients and minimizing potential toxicities. For example, at a very low $\mathrm{pH} \mathrm{Al} \mathrm{may} \mathrm{become} \mathrm{more} \mathrm{soluble} \mathrm{and} \mathrm{can} \mathrm{be} \mathrm{taken} \mathrm{up} \mathrm{by}$ roots - becoming toxic, $\mathrm{P}$ may become unavailable and $\mathrm{Ca}$ levels can be low. At high $\mathrm{pH}, \mathrm{Fe}$ and other micronutrients (except Mo) are rendered unavailable since they are locked up as insoluble hydroxides and carbonates (Somani, 1996).

\section{Management of Soil Acidity}

Lime, in its most pure form, is made up largely of $\mathrm{Ca}$. Calcium carbonate is a base, and therefore, has a neutralizing effect on acid (Edmeades et al., 2003; Kamprath, 1984). Lime improves base saturation and availability of $\mathrm{Ca}$ and $\mathrm{Mg}$. Fixation of $\mathrm{P}$ and $\mathrm{Mo}$ is reduced by inactivating the reactive constituents. Toxicity arising from excess soluble $\mathrm{Al}, \mathrm{Fe}$ and $\mathrm{Mn}$ is corrected and thereby root growth is promoted and uptake of nutrients is improved. Liming also stimulates microbial activity and enhances $\mathrm{N}$ fixation and $\mathrm{N}$ mineralization and hence, 
legumes are highly benefited from liming (Fageria and Baligar, 2008; Pilbeam and Morley, 2007). However, overliming can considerably reduce the bioavailability of micronutrients, such as $\mathrm{Zn}, \mathrm{Cu}, \mathrm{Fe}, \mathrm{Mn}$ and $\mathrm{B}$, which decreases with increasing $\mathrm{pH}$ (Fageria and Baligar, 2008). This can produce plant nutrient deficiencies, particularly that of Fe. Soil acidity limits or reduces crop production primarily by impairing root growth thereby reducing nutrient and water uptake (Marschner, 2011). Soil acidity converts available soil nutrients into unavailable forms and soils affected by soil acidity are poor in their basic cations, such as $\mathrm{Ca}, \mathrm{K}, \mathrm{Mg}$, and some micronutrients, which are essential to crop growth and development (Wang et al., 2006). The extent of damage posed by soil acidity varies from place to place depending on several factors, and there are occasions where total crop failure occurs due to soil acidity. Thus, the main effects of liming are increasing the available $\mathrm{P}$ through inactivation or precipitation of exchangeable and soluble $\mathrm{Al}$ and $\mathrm{Fe}$ hydroxides, increase in $\mathrm{pH}$, available $\mathrm{P}$, exchangeable cations and percent base saturation, and enhancing the growth density and length of root hairs for uptake of $\mathrm{P}$ (Marschner, 2011).

Soil acidity can be corrected easily by liming the soil, or adding basic materials to neutralize the acid present. The most economical liming materials and relatively easy to manage are calcitic or dolomitic agricultural limestone (Pilbeam and Morley, 2007; Rengel, 2011). Since these products are natural they are relatively insoluble in water, agricultural limestone must be very finely ground so it can be thoroughly mixed with the soil and allowed to react with soil's acidity.

In an attempt to address soil acidity problems, the application of lime has remarkably improved the response of barley and faba bean to P fertilizer application, which is otherwise, immobilized due to $\mathrm{P}$ fixation in the central highland Nitisol areas of Ethiopia (Figure 3 and 4). Buni (2014) reported that soil $\mathrm{pH}$ increased from 5.03 to 6.72 and exchangeable acidity (EA) was significantly reduced due to the application of $3.75 \mathrm{tlime} \mathrm{ha}^{-1}$ on Nitisol with an inherent property of high $\mathrm{P}$ fixation in southern Ethiopia (Table 2). Moreover, liming significantly increased CEC and available $\mathrm{P}$, and decreased available micronutrients except $\mathrm{Cu}$. The highest $\left(33.34 \mathrm{cmol}(+) \mathrm{kg}^{-1}\right)$ and lowest $\left(19.18 \mathrm{cmol}(+) \mathrm{kg}^{-1}\right)$ values of CEC were obtained from the highest lime rate and control treatment, respectively (Table 1).

Previous studies (Table 4) indicated that application of different rates of lime and $\mathrm{P}$ fertilizer significantly increased barley grain yield in the central highlands of Ethiopia (Beyene, 1987; Desalegn et al., 2017). According to Desalegn et al. (2017), the combined application of 1.65 $\mathrm{t}$ lime ha $\mathrm{ha}^{-1}$ and $30 \mathrm{~kg} \mathrm{P} \mathrm{ha}^{-1}$ resulted in $133 \%$ more grain yields of barley than the control (without $\mathrm{P}$ and lime). The highest yield of barley was obtained in the third year after application of lime, implying that the efficiency of lime was more in the subsequent year than the first and second year of its application (Beyene, 1987). Normally, calcium carbonate takes more time to be soluble in water than slaked lime which consists of mostly calcium hydroxide (Somani, 1996). Hillard et al. (1992) indicated that decreasing winter pasture productivity in un-limed Ultisols has been associated with increased soil acidity due to $\mathrm{N}$ fertilizer application. Thus, over three harvest years, rye grass yields increased $90-750 \%$ and $25-80 \%$ at the highest lime and $\mathrm{P}$ rates, respectively. In the second year, yield response to applied $\mathrm{P}$ was significantly less at the high lime rate, indicating that liming made soil $\mathrm{P}$ more plant available. Application of lime and $\mathrm{P}$ increased plant tissue $\mathrm{P}, \mathrm{Ca}$ and $\mathrm{Mg}$ concentrations (Agegnehu and Sommer, 2000b; Hillard et al., 1992). Anetor and Akinrinde (2007) reported that unamended soil remained acidic ( $\mathrm{pH} 4.8$ ), but liming raised $\mathrm{pH}(6.1-6.6)$, and resulted in maximum $\mathrm{P}$ release (15.1-17.3 $\mathrm{mg} \mathrm{kg}^{-1}$ ) compared to un-amended soil (4.2-7.1 $\mathrm{mg} \mathrm{P} \mathrm{kg}^{-1}$ ). The picture in Figure 3 shows the effect of lime on growth of barley in acidic soils.

According to Agegnehu et al. (2006) the application of lime at the rates of 1,3 and $5 \mathrm{tha}^{-1}$ resulted significantly in linear response with mean faba bean seed yield advantages of 45,77 and $81 \%$ over the control (Figure 4). Desalegn et al. (2017) showed that Application of 0.55, 1.1, 1.65 and $2.2 \mathrm{t}$ lime $\mathrm{ha}^{-1}$ decreased $\mathrm{Al}^{3+}$ by $0.88,1.11,1.20$ and 1.19 mill equivalents per $100 \mathrm{~g}$ of soil, and increased soil $\mathrm{pH}$ by $0.48,0.71,0.85$ and 1.1 units, respectively. Agegnehu et al. (2006) also indicated that soil $\mathrm{pH}$ consistently increased from 4.37 to 5.91 as lime rate increased. Conversely, the exchangeable acidity was significantly reduced from 1.32 to $0.12 \mathrm{cmol}(+) \mathrm{kg}^{-1}$ because of lime application. Yield increments showed direct relationship with the soil $\mathrm{pH}$ values and inverse relationship with exchangeable acidity, i.e. as the $\mathrm{pH}$ increased the yield also increased, but as the exchangeable acidity decreased the yield of faba bean increased and vice versa. Mahler et al. (1988) also found that seed yields of legumes were optimal between soil $\mathrm{pH}$ values of 5.7 and 7.2 and yields of pea could be increased by $30 \%$ due to lime application to soils with $\mathrm{pH}$ values less than 5.4. The picture in Figure 4 shows the effect of lime on growth of faba bean in acidic soils.

At the farm level, the economic rate at which farmers apply lime depends on net farm returns to lime application. Several factors need to be considered to evaluate the costs and benefits of lime application at the household level. These include expected yield increases, prices per unit of lime, transportation and application stages, as well as the expected number of years of enhanced productivity. All of these factors affect net farm returns of lime use. A rough calculation of net farm returns to lime application based on experimental results suggest that application of lime is generally profitable particularly when used in moderate amounts ranging from 2.0 to $2.2 \mathrm{t} \mathrm{ha}^{-1}$ in conjunction with other improved agricultural practices (use of inorganic and organic fertilizers, high yielding varieties and associated better agronomic practices). Accordingly, considering wheat and productivity improvements from $0.9 \mathrm{t} \mathrm{ha}^{-1}$ to 1.6 $\mathrm{t} \mathrm{ha}^{-1}$ due to lime use only, estimated gross and net returns are estimated at birr 7524 and birr $2324 \mathrm{ha}^{-1}$, respectively, from an average application of $2.2 \mathrm{t} \mathrm{lime} \mathrm{ha-}^{-1}$ (Table 5).

At a national level, widespread use of lime is expected to have remarkable economic benefits. Accurate quantitative estimates of national benefits from the use of agricultural lime, however, are fraught with uncertainties associated with the rate of increase in agricultural lime production, transportation and distribution. Such estimates are also sensitive to the level of public-private partnership attained in the provision of critical services such as credit and advisory services to farmers. Nonetheless, despite such uncertainties, three factors are crucial to estimating the 
possible impact of increased agricultural lime production and distribution in Ethiopia. The first factor relates to estimating the value added to the national economy from the increased production resulting from the use of agricultural lime. The second factor relates to savings in foreign exchange (lower import bills) due to decreased imports of basic agricultural commodities. The third factor is associated with the value of possible increases in exports of agricultural products such as soybean and coffee. Owing to lack of micro data and information, value added estimates to the national economy are based on productivity improvements (Table 6). Accordingly, assuming wheat is planted to all land rehabilitated and the same average returns prevail under actual production conditions as shown in Table 5, the total gross returns from the use of lime would be about birr 38.3 million in 2015 (base scenario). Further, assuming reclamation of acid soils goes as planned by the MoANR, the same average returns prevail under actual production conditions and current input-output prices hold in the future, the annual total gross and net value added to the economy from the use of lime would be birr 1.7 billion and 0.53 billion, respectively, by the end of GTP II. Correspondingly, the amount of lime required to gain the indicated value added would be about 500,000 tons. It is worth noting that only a small fraction of the acid soil areas are planned to be rehabilitated by the end of GTP II.

The other important impact of widespread use of lime in Ethiopia would be a substantial saving in foreign exchange due to lower import bills from reduced or complete substitution of imports of basic commodities such as wheat. In 2012, the country imported 1.1 million tons of wheat at a cost of 332.97 million USD (FAO, 2014). Such imports, however, could be eliminated by raising wheat productivity from the current average of $2.45 \mathrm{t} \mathrm{ha}^{-1}$ (CSA, 2016) to $3.13 \mathrm{t} \mathrm{ha}^{-1}$.

\section{Agricultural Significance and Yield Losses Due to Parasitic Weeds}

A considerable loss in growth and yield of many food and fodder crops is caused by root-parasitic flowering plants. Globally, Striga have a greater impact on human welfare than any other parasitic angiosperms because their hosts are subsistence crops in areas marginal for agriculture. In general, low soil fertility, nitrogen deficiency, well-drained soils, and water stress accentuate the severity of Striga damage to the hosts. These are typically the environmental conditions for Striga-hosts in the semi-arid to sub humid tropics. Nowadays, Striga is considered as the greatest single biotic constraint to food production in Africa, where the livelihood of 300 million people is adversely affected. In infested areas, yield losses associated with Striga damage are often significant, ranging from 40-100 percent (Bebawi and Farah, 1981; Lagoke et al., 1991; Ejeta et al., 1992). Moreover, it is predicted that grain production in Africa is potentially at even increasing risk in the future. This is because several factors that influence the occurrence and may accelerate the future spread and the infestation intensity of Striga species in agricultural cropping systems. These include the future adaptation of Striga to crops and to wide ecological amplitude, and a drop in soil fertility in tropical soils (Kroschel, 1998). The significant yield reductions result in little or no food at all for millions of subsistence farmers and consequently aggravate hunger and poverty.

Alectra vogelii is a serious pest in cowpea production in Africa. The parasite infection did not decrease cowpea dry matter production, but it significantly altered dry matter partioning by increasing the proportion of root dry matter (Rambakudzibga et al., 2002). Crop yield losses resulting from $A$. vogelii infestation range from 41 percent to total crop loss of highly susceptible cultivars (Lagoke et al., 1993). The yield reduction is mediated through the delayed onset of flowering, reduced number of flowers and pods, and reduced mass of pods and grain (Mugabe, 1983).

The damage caused by the parasites Orobanche on field and vegetable crops is significant in the Near East, South and East Europe and in various republics of the former Soviet Union. It causes yield losses ranging from 5-100 percent (Linke et al., 1989). For example, in Morocco, the infestation of $O$. crenata in food legumes caused yield losses of 32.7 percent on an average in five provinces in the year 1994, which was equal to a production loss of 14 389 tonnes (US\$8.6 million. (Geipert et al., 1996). As a result of the complete devastation caused by Orobanche in many areas, production methods had to be modified and/or cultivation of some susceptible hosts had to be abandoned.

Compared with non-parasitic weeds, the control of parasitic weeds has proved to be exceptionally difficult. The ability of the parasite to produce a tremendously high number of seeds, which can remain viable in the soil for more than ten years, and their intimate physiological interaction with their host plants, are the main difficulties that limit the development of successful control measures that can be accepted and used by subsistence farmers. However, several control methods have been tried for the control of parasitic weeds, including cultural and mechanical (crop rotation, trap and catch cropping, fallowing, hand-pulling, nitrogen fertilization, time and method of planting, intercropping and mixed cropping), physical (solarization), chemical (herbicides, artificial seed germination stimulants, e.g. ethylene, ethephon, strigol), use of resistant varieties, and biological. These methods of control were well reviewed by Parker and Riches (1993), and recently summarized in Kroschel (2001), and Omanya (2001). At on-farm level, the management of parasitic weeds is still unsatisfactory since - with the exception of the use of glyphosate in faba bean to control O. crenata present control methods are not efficient enough to control already the underground development stages of the parasites. At present, the restoration of infested fields can only succeed through the improvement of existing farming systems based on a sound analysis of the parasitic weed problem and the development of a sustainable long-term integrated control programme consisting of the more applicable control approaches that are compatible with existing farming systems and with farmer preference and income (Kroschel, 1999). The success of cultural measures becomes evident only in the long run and will not improve yields in the present crop, because of the long underground developmental phase as well as the high seed production and longevity (Parker and Riches, 1993). The income of the subsistence farmers is usually too low to justify the use of highly sophisticated technical inputs such as ethylene to trigger ineffective Striga seed germination, as used in North Carolina to eradicate S. asiatica, or with soil 
solarization. In addition to the cost, selectivity, low persistence and availability are major constraints that limit the successful usage of herbicides. In addition, the use of synthetic germination stimulants and application of high dosage of nitrogen fertilizer (more than $80 \mathrm{~kg} \mathrm{~N}^{-1}$, mainly as ammonium sulphate or urea), are not readily applicable in African farming systems (Kroschel et al., 1997). Few resistant lines for some host-parasite associations were reported (Lane et al., 1997) but resistance is often interfered by the large genetic diversity of the parasites. Recent successes have been achieved in biological control, but it has not led to practical field application owing to the difficulties associated with mass rearing, release, formulation and delivery systems.

Considering the constraints to a successful control of parasitic weeds so far, it is well recognized that no single method of control can provide an effective and economically acceptable solution. Therefore, an integrated control approach is essential, ideal and useful to smallscale farmers, in order to achieve sustainable crop production. The progress achieved in individual parasitic control measures has been previously summarized and discussed in this topic, may be of significance in contributing to the success of any proposed integrated approach through the accommodation of newly adaptive and applicable components. No standard integrated control package for parasitic weeds can be put forward; therefore it needs to be adjusted to individual cropping systems, local needs and preferences. In this context, the development and use of mathematical modelling tools may be helpful in adapting and optimizing control strategies to different agro-ecosystems (Manschadi et al. 1999).

Certain "key" factors of farming systems are directly related to the occurrence and infestation intensity of Striga, including: i) length of fallow; ii) weeding practice; iii) maintenance of soil fertility with the use of crop residues and organic manure; iv) crop rotation and the proportion of cereals (hosts) in the rotation; and v) the use of, and access to, external inputs (herbicides, fertilizers) and improved seeds (Kroschel, 1999). Analysing these key factors may provide possibilities for improving the cropping system, as well as identifying the best-suited control approaches according to farmers' specific situations. With regard to Striga, any ideal integrated control strategy should consider containment and control as well as the need to improve soil fertility in order to be successful in achieving sustainable crop production.

For an area that is heavily infested with Striga, where soybeans have a ready market, and maize, the staple cereal can be easily purchased on the local market, an integrated approach might include the following components: rotation with soybeans, using a variety that is high yielding and well adapted to the region (Ransom, 1999). In order to maintain on-farm productivity and production, it is probably more important to select the most productive and/or easily marketed variety as opposed to one that stimulates the most Striga seeds but is otherwise a poor performer. With yield and adaptation being equal, however, the most effective Striga seed germination stimulator should be recommended. Since maize is the staple cereal, probably only half of the farm can be rotated to a crop other than maize. Within the maize crop, the farmer should be encouraged to apply as much organic fertiliser as possible (i.e. Crop residue, manure, etc.) and the recommended (or the maximum amount affordable) of the inorganic fertilizers. The farmer can intercrop his maize crop with other species if desired, but it is not necessary to achieve maximum control. If the numbers emerging are not overwhelming, Striga should be hand-weeded to ensure that there are no new additions to the Striga seed bank. After harvest, all crop residues should be ploughed back into the soil.

For an area where there is a limited market for grain legumes, wheat or teff as non-Striga hosts can be grown. The following integrated approach might be considered: i) Wheat or teff should be grown in the most severely affected fields. Growing these non-hosts would allow for a staple cereal to be produced. ii) Every effort to improve the fertility of soil should be utilized, which should include fertilizers, manure and crop residues. iii) If sorghum or maize is required by the farmer, local varieties of sorghum which show considerable tolerance to Striga should be grown in preference to maize. iv) Hand-weeding or the use of 2, 4-D to stop reproduction of any emerged Striga should also be used, depending on the Striga pressure and availability of labour and chemicals (Ransom, 1999).

In Ethiopia, an integrated Striga management package was recently begun to be implemented through funds provided by the Office of Foreign Disaster Assistance (OFDA) of the USAID. It includes seed of Striga-resistant sorghum (INTSORMIL varieties or Brhan), nitrogen fertilizer, and the use of tied ridging as a water conservation measure. In the summer of 2003, a total of one thousand Ethiopian farmers in four Striga endemic regions will participate in this management programme (Ejeta, 2002). In Cote d'Ivoire, the $S$. hermonthica control package including the use of Striga tolerant maize varieties (ACR 94TZL Comp 5-w) intercropped or in rotation with legumes cultivars (soybean, cowpea) was reported to be effective in reducing the parasite infestation and increasing yields of maize (Louise et al., 2001).

A detailed review by Pieterse et al. (1992) and Parker and Riches (1993) suggesting the possible combinations of relevant control methods for Orobanche in a number of susceptible individual crops, still remains very important. However, the following integrated control approach was suggested by Dhanapal et al. (2001) for O. cernua control in tobacco in India; Grow trap crops (sunnhemp/greengram) in the early spring and incorporate in situ 45 days after sowing, transplant tobacco after 15-20 days, take up general weeding within 45 days after transplanting (DAT), apply glyphosate at 60 DAT at $0.5 \mathrm{~kg}$ a.i. ha ${ }^{-1}$ (or less), remove the remaining few broomrape spikes by hand or apply plant oils to prevent seed formation.

For $O$. crenata control in faba bean in Morocco, the package should include; treatment with glyphosate, crop rotation with non-host and avoidance of planting host crops for at least 3-4 years in the same field, hand weeding of the remaining Orobanche shoots before and after crop harvest and removal of shoots from the field and burning (Kroschel, 2001).

\section{Crop Water Requirement and Irrigation Scheduling}

Based on the ETc and FAO, the available moisture depletion level had been calculated and field experiment was done for two years to evaluate the effect of deferent 
moisture depletion level on maize yield and water use efficiency (Table 8). The biomass yield and grain yield data in 2011 showed significant differences $(\mathrm{P}<0.05)$ among irrigation treatments. Reducing or increasing the amount of water application interval was significantly affect yield of maize at Pawe Vertisoil of village-24. The highest grain yield increment observed when the application of water was 140\% ASMDL (Available Soil Moisture Depletion Level) and it is $3777 \mathrm{~kg} / \mathrm{ha}$ which is $52 \%$ greater that the least yield obtained at treatment 1 (60\% ASMDL). The highest biomass yield was also obtained at 140\% ASMDL; that was $16,923 \mathrm{~kg} / \mathrm{ha}$ which is $50 \%$ greater than the least biomass yield obtained at treatment 2 (80\% ASMDL). Besides; in 2012, it was observed that there was no significant different at $(\mathrm{P}<0.05)$ among or interval of biomass and grain yield of maize. The highest grain yield increment was observed on treatment 5 (140\% ASMDL) that was $2951 \mathrm{~kg} / \mathrm{ha}$ which is $40 \%$ greater than the least yield obtained at treatment 3 (100\% ASMDL). The greatest biomass yield was also obtained at treatment $5(140 \%$ ASMDL), that is $13,072 \mathrm{~kg} / \mathrm{ha}$ which was about $26 \%$ greater than the least biomass yield obtained at treatment 4 (120\% ASMDL). Both years analyses showed that the maximum biomass and obtained grain yield was obtained at optimal irrigation regime of $140 \%$ ASMDL. Therefore, $140 \%$ of ASMDL was identified as best performing for Vertisoil irrigated fields in the study area (Table 8).

The effects of testing different levels of allowable moisture depletion level using maize crop were highly significant at $(\mathrm{P}<0.05)$. In 2011, the maximum efficiency of the crop to convert irrigation water to grain was high in treatment $2\left(80 \%\right.$ ASMDL) which had $1.970 \mathrm{~kg} / \mathrm{m}^{3}$ and $2.103 \mathrm{~kg} / \mathrm{m}^{3}(100 \% \mathrm{ASMDL})$ in 2012 . However; the minimum water use efficiency was $1.027 \mathrm{~kg} / \mathrm{m}^{3}$ and 1.220 $\mathrm{kg} / \mathrm{m}^{3}$ in 2011 and 2012, respectively. The response of crop water use efficiency had an increasing tendency when the soil moisture depletion increased from 60 to $100 \%$ of ASMDL, but at $140 \%$ ASMDL which received longest irrigation interval and crop stress and relatively led to reduced water use efficiency (Table 8).

\section{Conclusions}

Considering the country's agriculture dependent economy, increasing food demand as a result of increasing population and insufficiency of rain-fed agriculture, it is evident that the country's plan to expand and promote irrigated agriculture is foreseeable. Provided that the likely target of planned expansion would not be out of the highland or lowland areas which are being affected or vulnerable to waterlogging and salinity problems respectively; drainage is and must be inevitable. The literatures referred in this paper signals the importance of drainage in boosting crop yields by controlling the above mentioned drainage problems. It can be concluded that drainage is as important as irrigation for a productive and profitable irrigated agriculture that could help the country achieve it planned development goal. The unavoidable challenges that might be faced in the process are related to costs and technology in design, implementation, operation and maintenance of drainage systems. But this might be copped by introducing low cost technologies like BBF for the small scale irrigators and the modern surface and sub- surface drainage for the medium and large scale irrigation scheme. Comprehensive studies needs to be conducted to thoroughly investigate the effectiveness of BBF and other technologies, map the spatial and temporal waterlogging, salinity, irrigation and drainage status and their impact on the agricultural productivities and development of the country. Under all circumstances, agricultural water management should be given special attention otherwise drainage without proper water management will be futile. The importance of agronomic measure including salt tolerant crop genotype is not undermined and should be practiced in combination with drainage or even solely. Moreover, governments and other concerned organizations needs render due the required financial commitments and the political will to design and implement effective drainage systems.

The main effects of liming are increasing the available $\mathrm{P}$ through inactivation or precipitation of exchangeable and soluble $\mathrm{Al}$ and $\mathrm{Fe}$ hydroxides, increase in $\mathrm{pH}$, available $\mathrm{P}$, exchangeable cations and percent base saturation, and enhancing the growth density and length of root hairs for uptake of P. Over the last decade and with the help of innovative technologies, basic and applied research efforts have generated a wealth of scientific knowledge for the better understanding and improvement of sustainable integrated parasitic weed management. As has been summarized and discussed, the significant progress achieved in the various individual parasitic weed control measures are highly relevant to the success of any proposed and/or applied integrated control approach through the accommodation of newly adaptive and applicable components. However, although the words 'integrated control' have become 'magic words' in parasitic weed management, no long-term studies exist in which integrated control has been tested and proved to be the key to their control in the field. Since no standard integrated control 'package' for parasitic weeds can be put forward, relevant control options need to be adjusted to individual cropping systems, local needs and farmers' preferences.

\section{References}

Abbott CL, Leeds-Harrison PB. 1998. Research priorities for agricultural drainage in developing countries. HR Wallingford. Firm.

Abebe M. 2007. Nature and management of acid soils in Ethiopia. Abebe TF, Alamirew T, Abegaz F. 2015. Appraisal and mapping of soil salinity problem in Amibara irrigation farms, Middle Awash basin, Ethiopia. International Journal of Innovation and Scientific Research, 13(1): 298-314.

Abegaz F. 1996. Effect of subsurface drainage system on groundwater table, soil salinity and crop yield in Melka Sadi pilot drainage scheme. In. Proceedings of the Conference of the Agronomy and Crop Physiology Society of Ethiopia, Addis Abeba (Ethiopia), 30-31 ACPSE.

Abraha B, Yohannes G. 2013.The role of seed priming in improving seedling growth of maize (Zea mays L.) under salt stress at field conditions. Agricultural Sciences, 4(12): 666672. DOI: $10.4236 /$ as.2013.412089

Agegnehu G, Fikre A, Tadesse A. 2006. Cropping Systems, Soil Fertility and Crop Management Research on Food Legumes in the Central Highlands of Ethiopia: A Review of Major Achievements of a Decade. kemal Ali, Gemechu Keneni, Seid Ahmed, Rajendra S. Malhotra, Surendra Beniwal and Khaled Makkouk, 135-145. 
Agegnehu G, Sommer K. 2000. Optimization of the efficiency of phosphate fertilizers in acidic-ferralitic soils of the humid tropics. Ethiopian Journal of Natural Resources, 2(1): 63-77.

Asamenew G, Beyene H, Haile A, Negatu W. 1993. Technology validation and transfer.

Asamenew G, Jutzi SC, Tedla A, McIntire J, Haque I, Stares J. 1988. Economic evaluation of improved Vertisol drainage for food crop production in the Ethiopian highlands. Management of Vertisols in Sub-Saharan Africa, edited by S. C. Jutzi, 263-283.

Asfaw KG, Itanna F. 2009. Screening some tef [Eragrostis tef (Zucc.) Trotter] accessions/varieties for salt tolerance during germination and seedling stage. Momona Ethiopian Journal of Science, 1(2). DOI: 10.4314/mejs.v1i2.46046

Awulachew SB. 2019. Irrigation potential in Ethiopia: Constraints and opportunities for enhancing the system. Gates Open Res, 3. DOI: 10.21955/gatesopenres.1114943.1

Ayars JE, Hanson BR. 2014. Integrated Irrigation and Drainage Water Management. In: Chang AC, Brawer Silva D (eds) Salinity and Drainage in San Joaquin Valley, California: Science, Technology, and Policy. Springer Netherlands, Dordrecht, pp 249-276. DOI: 10.1007/978-94-007-68512_10

Ayenew T. 2007. Water management problems in the Ethiopian rift: Challenges for development. Journal of African Earth Sciences, $\quad 48(2-3)$ : 222-236. DOI: 10.1016/j.jafrearsci.2006.05.010

Bai ZG, Dent DL, Olsson L, Schaepman ME. 2008. Proxy global assessment of land degradation. Soil use and management, 24(3): 223-234. DOI: 10.1111/j.1475-2743.2008.00169.x

Baquy M, Li JY, Xu CY, Mehmood K, Xu RK. 2017. Determination of critical $\mathrm{pH}$ and $\mathrm{Al}$ concentration of acidic Ultisols for wheat and canola crops. Solid Earth, 8(1): 149159. DOI: $10.5194 / \mathrm{se}-8-149-2017$

Behailu M, Haile M. 2002. Water harvesting in northern Ethiopia: Environmental, health and socio-economic impacts. Integrated water and land management research and capacity building priorities for Ethiopia, 185.

Bekele G. 2005. The Nature and properties of salt affected soils in middle Awash Valley of Ethiopia Journal of Soil Science, 8: $23-30$

Bekele T, Höfner W. 1993. Effects of different phosphate fertilizers on yield of barley and rape seed on reddish brown soils of the Ethiopian highlands. Fertilizer research, 34(3): 243-250. DOI: 10.1007/BF00750570

Beyene D. 1987. Effects of Liming and N and P Fertilizers on Grain Yield of Barley. Ethiopian Journal of Agricultural Sciences.

Brown TT, Koenig RT, Huggins DR, Harsh JB, Rossi RE. 2008. Lime effects on soil acidity, crop yield, and aluminum chemistry in direct-seeded cropping systems. Soil Science Society of America Journal, 72(3): 634-640. DOI: 10.2136/sssaj2007.0061

Buni A. 2014. Effects of liming acidic soils on improving soil properties and yield of haricot bean. J. Environ. Anal. Toxicol, 5(1): 1-4. DOI: 10.4172/2161-0525.1000248

Central Statistical Agency. CSA. 2016. Report on Area and Production of Major Crops. Agricultural Sample Survey 2013/14, CSA (Central Statistical Agency). Volume 1. Addis Ababa, Ethiopia

Datta KK, Jong Cd. 2002. Adverse effect of waterlogging and soil salinity on crop and land productivity in northwest region of Haryana, India Agricultural Water Management, 57: 223 238. DOI: 10.1016/S0378-3774(02)00058-6

Desalegn T, Alemu G, Adella A, Debele T. 2017. Effect of lime and phosphorus fertilizer on acid soils and barley (Hordeum vulgare L.) performance in the central highlands of Ethiopia. Experimental Agriculture, 53(3): 432-444. DOI: 10.1017/S0014479716000491
Dinka MO, Ndambuki JM. 2014. Identifying the potential causes of waterlogging in irrigated agriculture: the case of the wonjishoa sugar cane plantation (Ethiopia). Irrigation and drainage, 63(1): 80-92. DOI:10.1002/ird.1791

Dubale P, Menkir M, Zewdie M, Zeray L. 2002. Agriculture, irrigation and drainage research in the past and the future Integrated water and land management research and capacity building priorities for Ethiopia, 38

Dubale P. 2002. Present and future trends in natural resources management in agriculture: An overview. Integrated water and land management research and capacity building priorities for Ethiopia, 29

Edmeades, D., Ridley, A., and Rengel, Z. 2003. Handbook of soil acidity. Handbook of soil acidity.

Ethiopian Institute of Agricultural Research. EIAR. 2006. Assessment of Salt Affected Soils in Ethiopia and Recommendations and Management Options for their Sustainable Utilization. Taskforce Report, Addis Ababa, Ethiopia

El Wakeel A, Astatke A. 1996. Intensification of agriculture on vertisols to minimize land degradation in parts of the Ethiopian highlands. Land Degradation \& Development, 7(1): 57-67. Doi: 10.1002/(SICI)1099-145X(199603)

Erkossa T, Gizaw A, Stahr K. 2004. Land preparation methods efficiency on the highland Vertisols of Ethiopia. Irrigation and Drainage, 53(1): 69-75. DOI: 10.1002/ird.116

Eswaran H, Almaraz R, van den Berg E, Reich P. 1997. An assessment of the soil resources of Africa in relation to productivity. Geoderma, 77(1): 1-8. DOI: $10.1016 /$ S00167061(97)00007-4

Eswaran H, Reich P, Beinroth F. 1997. Global distribution of soils with acidity. 159-164. AC Moniz, AMC Furlani, RE Schaffert, NK Fageria, CA Rosolem, H. Cantarella.

Fageria NK, Baligar VC. 2008. Ameliorating soil acidity of tropical Oxisols by liming for sustainable crop production. Advances in agronomy, 99: 345-399. DOI: 10.1016/S00652113(08)00407-0

Fageria NK, Nascente AS. 2014. Management of soil acidity of South American soils for sustainable crop production. In Advances in Agronomy, 128: 221-275. Academic Press. DOI: 10.1016/B978-0-12-802139-2.00006-8

Food and Agricultural Organization. FAO. 2014. Analysis of price incentives for wheat in Ethiopia. FAO, Rome, Italy.

Food and Agricultural Organization. FAO. 2014. Irrigation in Africa in Figures. FAO water report 29, Rome, Italy.

Fox RH. 1979. Soil pH, Aluminum Saturation, and Corn Grain Yield. Soil science, 127(6): 330-334.

Gadissa T, Chemeda D. 2009. Effects of drip irrigation levels and planting methods on yield and yield components of green pepper (Capsicum annuum, L.) in Bako, Ethiopia. Agricultural Water Management, 96(11): 1673-1678. DOI: 10.1016/j.agwat.2009.07.004

Gebrehiwot KA, Gebrewahid MG. 2016. The need for agricultural water management in sub-saharan Africa. Journal of Water Resource and Protection, 8(09): 835. DOI: 10.4236/jwarp.2016.89068

Geressu K, Gezaghegne M. 2008. Response of some lowland growing sorghum (Sorghum bicolor L. Moench) accessions to salt stress during germination and seedling growth. African Journal of Agricultural Research, 3(1): 044-48.

Haile GG, Kasa AK. 2015. Irrigation in Ethiopia: A review Academia Journal of Agricultural Research, 3:264-269 DOI: 10.15413/ajar.2015.0141

Haile GG, Kasa AK. 2015. Irrigation in Ethiopia: A review. Acad. J. Agric. Res, (10): 264-269.

Haynes RJ, Mokolobate MS. 2001. Amelioration of Al toxicity and $\mathrm{P}$ deficiency in acid soils by additions of organic residues: a critical review of the phenomenon and the mechanisms involved. Nutrient cycling in agroecosystems, 59(1): 47-63. DOI: 10.1023/A:1009823600950 
Hillard JB, Haby VA, Hons FM. 1992. Annual ryegrass response to limestone and phosphorus on an Ultisol. Journal of plant nutrition, $15(8)$ : $1253-1268 . \quad$ DOI: $10.1080 / 01904169209364394$

Jutzi SC. 1987. Anderson FM, Astatke A. Low-cost modifications of the traditional Ethiopian tine plough for land shaping and surface drainage of heavy clay soils: Preliminary results from on-farm verification trials. ILCA Bull, 27: 25-31

Jutzi SC. 1989. The Ethiopian Vertisols: a vast natural resource, but considerably underutilized. In 1 . Natural Resources Conservation Conference, Addis Ababa (Ethiopia), 7-8. IAR.

Kamprath EJ. 1984. Crop response to lime on soils in the tropics. Soil acidity and liming, 349-368.

Kebede K, Bekelle E. 2008. Tillage effect on soil moisture storage and wheat yield on the vertisols of north central highlands of Ethiopia. Ethiopian Journal of Environmental Studies and Management, 1(2): 49-55. .DOI: 10.4314/ejesm.v1i2.41580 AJOL African Journals Online

Keneni G, Jarso M, Asmamaw B. 2002. The role of drainage and genotype in improving the productivity of Faba Bean on waterlogged vertisols. Ethiopian Journal of Natural Resources.

Kochian LV, Hoekenga OA, Pineros MA. 2004. How do crop plants tolerate acid soils? Mechanisms of aluminum tolerance and phosphorous efficiency. Annu. Rev. Plant Biol, 55: 459493. DOI: 10.1146/annurev.arplant.55.031903.141655

Lawlor DW. Mengel, K. and Kirkby, EA. 2004. Principles of plant nutrition. Oxford University Press. DOI: 10.1093/aob/mch063

Li S, Duan Y, Guo T, Zhang P, He P, Johnston A, Shcherbakov A. 2015. Potassium management in potato production in Northwest region of China. Field Crops Research, 174: 4854. DOI: 10.1016/j.fcr.2015.01.010

Ma JF, Ryan PR, Delhaize E. 2001. Aluminium tolerance in plants and the complexing role of organic acids. Trends in plant science, 6(6): 273-278. DOI: 10.1016/S13601385(01)01961-6

Mahler RL, Saxena MC, Aeschlimann J. 1988. Soil fertility requirements of pea, lentil, chickpea and faba bean. InWorld crops: Cool season food legumes, pp. 279-289. Springer, Dordrecht. DOI: 10.1007/978-94-009-2764-3_27

Mamo T, Astatke A, Srivastava KL, Dibabe A. 1993. Improved management of Vertisols for sustainable crop-livestock production in the Ethiopian highlands: Synthesis report 19861992. eds. vol 95-018632. CIMMYT. Technical Committee of the Joint Vertisol Project, Addis Ababa (Ethiopia).

Mamo T, Haque I. 1991. Phosphorus status of some Ethiopian soils, II. Forms and distribution of inorganic phosphates and their relation to available phosphorus. Tropical Agriculture, 68(1): 2-8.

Marschner H. 2011. Marschner's mineral nutrition of higher plants. Academic press London.

Omogbohu Anetor M, Akinkunmi Akinrinde E. 2007. Lime effectiveness of some fertilizers in a tropical acid alfisol. Journal of Central European Agriculture, 8(1): 17-24.

Pilbeam, D. J. Morley, P. S. 2007. Calcium. Hand book of plant nutrition. In: Barker, A.V., Pilbeam, D.J. (eds.). CRC: Taylor and Francis, New York, pp. 121-144.
Poss R, Saragoni H. 1992. Leaching of nitrate, calcium and magnesium under maize cultivation on an oxisol in Togo. Fertilizer research, 33(2): 123-133. DOI: 10.1007/BF01051167

Regassa H, Agegnehu G. 2011. Potentials and limitations of acid soils in the highlands of Ethiopia: a review. Barley research and development in Ethiopia, 103

Rengel Z. 2011. Soil pH, soil health and climate change. In Soil health and climate change, pp. 69-85. Springer, Berlin, Heidelberg. DOI: 10.1007/978-3-642-20256-8_4

Rhoades JD. 1997. Sustainability of irrigation: An overview of salinity problems and control strategies. US Salinity Laboratory, Riverside, California.

Roem, W. J., and Berendse, F. 2000. Soil acidity and nutrient supply ratio as possible factors determining changes in plant species diversity in grassland and heathland communities. Biol. Conserv, 92, 151- 161.

Ruffeis D, Loiskandl W, Spendlingwimmer R, Schonerklee M, Awulachew SB, Boelee E, Wallner K. 2008. Environmental impact analysis of two large scale irrigation schemes in Ethiopia.

Sanchez PA. 1977. Properties and Management of Soils in the Tropics. Soil science, 124(3): 187.

Singh A. 2015. Soil salinization and waterlogging: A threat to environment and agricultural sustainability Ecological Indicators, 57: 128-130. DOI: 10.1016/j.ecolind.2015.04.027

Somani LL. 1996. Crop production in acid soils. Agrotech Publishing Academy, $1^{\text {st }}$ edition/Ed. Agrotech Publishing Academy, New Delhi.

Taddese G, Sonder K, Peden D. 2003. The water of the Awash River Basin a future challenge to Ethiopia International Livestock Research Institute, Addis Ababa

Taddese G. 2001. Land degradation: a challenge to Ethiopia. Environmental management, 27(6): 815-824. DOI: $10.1007 / \mathrm{s} 002670010190$

Triantafilis J, Ahmed MF, Odeh IO, Warr B. 2002. Soil salinisation risk assessment using saline irrigation water in the lower Namoi valley. InProceedings 11 th Australian Cotton Conference, Brisbane, Queensland, Australia, pp. 495-508.

Tully K, Sullivan C, Weil R, Sanchez P. 2015. The state of soil degradation in Sub-Saharan Africa: Baselines, trajectories, and solutions. Sustainability, 7(6): 6523-6552. DOI: $10.3390 /$ su7066523

United Nations, Department of Economic and Social Affairs, Population Division (UN DESA). 2015. International migrant stock 2015. Retrieved April 2019 from http://www.un.org/en/development/desa/population/migratio n/data/estimates2/estimates15.shtml

Van Den Berg M, Ruben R. 2006. Small-Scale irrigation and income distribution in Ethiopia The Journal of Development Studies, 42: 868-880 DOI: 10.1080/00220380600742142

Wang JP, Raman H, Zhang GP, Mendham N, Zhou MX. 2006. Aluminium tolerance in barley (Hordeum vulgare L.): physiological mechanisms, genetics and screening methods. Journal of Zhejiang University Science B, 7(10): 769-787. DOI: 10.1631/jzus.2006.B0769

Wichelns D, Qadir M. 2015. Achieving sustainable irrigation requires effective management of salts, soil salinity, and shallow groundwater Agricultural Water Management, 157: 31-38 DOI: 10.1016/j.agwat.2014.08.016 